\title{
Effects of Flumetazone on Exposed Dental Pulp of Dogs
}

\author{
I. CAPÍK, V. LEDECKÝ, A. ŠEVČÍK \\ Department of Surgery, Orthopaedics and Radiology, \\ University of Veterinary Medicine, Košice, Slovak Republic \\ Received February 25, 2002 \\ Accepted May 26, 2003
}

\begin{abstract}
Capík I., V. Ledecký, A. Ševčík: Effects of Flumetazone on Exposed Dental Pulp of Dogs. Acta Vet. Brno 2003, 72: 279-283.

Dental pulp metabolism plays very important role throughout the tooth life. Its role is essential particularly in the first two-three years. This is the time of the highest dentin deposition which provides sufficient firmness to withstand common everyday trauma. This study compared the systemic influence of corticosteroid (flumetazone-Acutol Lösung) on dental pulp vitality after partial pulpectomy performed within $24 \mathrm{~h}$ to four days after trauma. Ten mongrel dogs were used in the study. They were anaesthetised throughout all experimental procedures. Forty canine teeth were fractured at the coronal third of crowns. Five dogs with 20 fractured canine teeth were treated with antibiotic amoxicilin (Clamoxyl) $15 \mathrm{mg} / \mathrm{kg}^{-1}$ i.m. every $48 \mathrm{~h}$ until six days after the vital pulpotomy. The second group was treated with amoxicilin and flumetazone $0.0125 \mathrm{mg} / \mathrm{kg}^{-1}$ i.m. $(0.05 \mathrm{ml} / 2 \mathrm{~kg})$ administered during the first two days after pulp exposure.

$\mathrm{X}$-ray examination carried out two and three months after the therapy and physical examination (opening of the pulp cavity) in dubious cases proved that intramuscularly administered flumetazone influenced non-significantly the vitality of dental pulp of teeth subjected to vital pulpotomy later than $48 \mathrm{~h}$ after the trauma $(p \leq 0.59)$. Despite its non-significant influence it may increase the probability of conservation of the dental pulp and subsequent continuous dentin deposition especially in maturing teeth.

Dental pulp, partial pulpectomy, endodontics, corticosteroid, dog, radiological examination
\end{abstract}

Dental pulp consists of connective tissue. It differs from the other connective tissues by lack of epithelium and the presence of odontoblasts. The pulp is a terminal organ in terms of neural and vascular functions.

Common injuries of the dental pulp include traumatic injuries due to concussive shock, and thermal and infection injuries. When traumatized by a concussive shock, the tooth becomes inflamed (pulpitis) and swells within its dentinal shell (pulpal oedema), or it haemorrhages (pulpal haemorrhage). Clinically, the first signs of dental pulp inflammation are hyperaemia, followed by painful symptomatic pulpitis that may develop into a painless but irreversible condition. This leads to necrosis of the dental pulp.

After secondary exposure to a coronal fracture it is only a matter of time before pathogenic bacteria descend into the pulp canal to cause an abscess either within the canal itself or periapically by extension of the infection.

Eisner (1992) recommends endodontic treatment such as partial pulpectomy for recent fractures to preserve the dental pulp in a healthy state. This procedure is indicated within $48 \mathrm{~h}$ after the fracture of a mature tooth. This period can be extended to two or three weeks after the fracture of an incompletely developed adult tooth.

One exception to the 48-h rule is when the risk of failure can be accepted in order to allow a young tooth (in animals younger than 18 months) to develop a thicker dentinal wall, to complete apexigenesis (physiological lengthening of root and apical closure) and to become a better developed tooth as recorded Tholen (1983). 
Even if the tooth eventually dies, it has become more developed and the root canal therapy can then be performed. And although dead, the mature tooth will have a thicker, stronger dentinal wall, which increases its ability to remain functional and to withstand common everyday trauma.

It has been suggested that calcium hydroxide has a beneficial effect on the inflamed pulp tissue because of its high $\mathrm{pH}$, which might modify the environmental $\mathrm{pH}$ to the levels more favourable for cellular activity and thus for the repair processes. According to Nyborg (1958) investigations on the cariously exposed pulp have not confirmed any positive effect of calcium hydroxide. Tronstad and Mjör (1972) reported a beneficial effect on healing of calcium hydroxide applied to exposed monkey pulp with experimentally induced pulpitis.

Cvek (1978) and Cvek and Lundberg (1983) described very favourable clinical, roentgenological, and histological results following partial pulpectomy and capping with calcium hydroxide of traumatically exposed healthy human pulp. The healing did not seem to be influenced by factors such as exposure time, degree of exposure, or stage of the root development. Histological studies of accidentally exposed pulp in humans and monkeys showed only superficial inflammation following exposure for up to seven days. This was said to be due to the free exposure that permitted salivary rinsing and excluded the impact of debris.

Pavlica et al. (2000) recorded less inflamation and a thicker cover from well-formed, canalised tertiary dentine after partial pulpectomy in comparison with direct pulp capping. On the basis of these results, they recommend the radical method of vital amputation-partial pulpectomy as the most suitable approach for retaining the vitality of teeth with directly exposed pulp.

Various corticosteroids have been incorporated into calcium hydroxide cements or pastes in order to prevent or reduce pulpal inflammation and to relieve pain. Uitto et al. (1975) recorded that corticosteroids cause degenerative changes in the tissue and reduce the pulpal ability to form a hard tissue barrier in the presence of calcium hydroxide. Concerning the addition of corticosteroids to calcium hydroxide-containing pulp-capping agents, no biologically aceptable histological results have been reported so far.

The purpose of the present study was to determine radiologically the effect of systemically administered corticosteroids on endodontically treated (partial pulpectomy) fractured teeth in dogs, $20 \pm 2$ month-old. The dental pulps were examined daily before endodontic therapy by adspection to diagnose the presence of pulp oedema at the fracture line and any changes in colour.

\section{Materials and Methods}

The experiments conformed to the regulations of Ethic Committee of the University of Veterinary Medicine in Košice, Slovakia. Ten dogs of mixed breeds weighing 8-12 kg, $20 \pm 2$-month-old, were used in the study. The dogs were divided into two groups $(n=5)$. They were anaesthetised throughout all experimental procedures. Anaesthesia was induced by intravenous administration of $0.5 \mathrm{mg} / \mathrm{kg}^{-1}$ body weight of diazepam and $4 \mathrm{mg} / \mathrm{kg}^{-1}$ of ketamine followed by 1 to $2 \%$ halothane for the maintenance of anaesthesia.

The canine pulp chambers were opened by amputation of the coronal third of the crowns using a high-speed dental bur and extraction forceps, avoiding dental pulp concussion in all dogs. Group 1 was treated with antibiotic amoxicillin (Clamoxyl) $15 \mathrm{mg} / \mathrm{kg}^{-1}$ administered i. m. every $48 \mathrm{~h}$, and by vital pulpotomy, performed in 24-h intervals until $96 \mathrm{~h}$ after the occurrence of the fracture.

Group 2 was also treated with antibiotics in the same manner as Group 1 and also with flumetazone (Acutol Lösung) $0.0125 \mathrm{mg} / \mathrm{kg}^{-1} \mathrm{i}$.m. within the first two days after trauma. The vital pulpotomy was performed in the same way as in the first group.

The pulp amputation was done with a diamond dental bur in the coronal part of teeth. The time necessary for haemostasis was noted and compared between different groups of teeth within each group of dogs and between the two experimental groups of dogs. Bleeding was stopped by gently placing a sterile cotton pellet on the dental pulp for $2 \mathrm{~min}$, followed by placement of a sterile cotton pellet in 1-min intervals in the case of continuing bleeding.

After haemostasis, the pulp stups were disinfected with $0.25 \%$ chlorhexidine for 1 min and $\mathrm{Ca}(\mathrm{OH})_{2}$ paste, glassionomer cement and photocomposite were applied. Each tooth was examined radiographically at 2 and 3 months after the therapy. Antibiotics were administered intramuscularly to both groups of dogs for subsequent 6 days following endodontic therapy. 


\section{Results}

Table 1 and Fig. 1 (Plate XIV) show the times needed for haemostasis after vital pulpotomy in teeth treated in 24-h intervals.

The amputated pulp bled longer in dogs of Group 1. The longest bleeding time was seen in dogs after $48 \mathrm{~h}$ in both groups and then it kept decreasing up to $96 \mathrm{~h}$. Whereas Group 2 showed a gradual continuous decrease in bleeding times, Group 1 showed a marked decrease during the last $24 \mathrm{~h}$ of examination.

Fig. 2 shows the results of vital pulpotomy in teeth of the same group and differences between both groups. The vital pulpotomy was fully successful in both groups treated within $48 \mathrm{~h}$ after the trauma.

Adspection after $48 \mathrm{~h}$ showed the presence of pulp oedema seen as $0.5-1 \mathrm{~mm}$ pulp prominence over the fracture line in both groups.

In Group 1, the oedema decreased $72 \mathrm{~h}$ after the trauma and simultaneous change of colour from pink to anaemic was observed. In Group 2 no changes in clinical signs were observed at that time in comparison with clinical signs after $48 \mathrm{~h}$.

The pulp oedema was seen in Group 2 even $96 \mathrm{~h}$ after the trauma but the colour of pulp became brighter (pinkish). In Group 1, the pulp turned white.

Radiological examination in Group 1, did not confirm any radiological signs of dentinal bridging two months after the therapy. Group 2 showed signs of dentinal bridging in the teeth treated up to $48 \mathrm{~h}$ (Fig. 1). The teeth treated later had negative roentgenological findings.

Three months later, roentgenological examination showed the presence of dentinal bridge in the teeth of both groups of dogs treated within $48 \mathrm{~h}$ after the trauma. The dentinal bridge was more radioopaque in Group 2.

No radiological signs of dentinal bridging were seen in the teeth of Group 1, treated after $72 \mathrm{~h}$, but a widened periodontal space was present in three teeth at the apical region as a result of periapical infection (Fig. 2). Weak bleeding was seen in remaining two canine teeth after opening the pulp chambers.

The three teeth treated endodontically $72 \mathrm{~h}$ after fracture remained vital in Group 2 of dogs and showed moderate roentgenological signs of dentinal bridging, observed particularly at peripheral sites (Plate XV, Fig. 3).

Roentgenological examination of teeth treated after $96 \mathrm{~h}$ showed weak suggestions of dentinal bridging in two teeth from the second group.

Of 20 teeth in each group of dogs 12 remained vital in Group 1, and 15 in Group 2. No significant inter-group differences were detected by $\mathrm{c}^{2}$ test $(p \leq 0.59)$.

\section{Discussion}

This study showed that i.m. administration of the corticosteroid flumetazone after dental pulp exposure did not influence the therapeutic results of vital pulpotomy in teeth treated within $48 \mathrm{~h}$ after the fracture.

Treatment at this time ensured $100 \%$ success of vital pulpotomy in both groups regadles of the medical therapy used. Intramuscular administration of flumetazone seemed to play a certain positive role in teeth treated with vital pulpotomy after $48 \mathrm{~h}$ from dental pulp exposure, though increasing interval decreased the therapeutic success. Treatment within 48 to $96 \mathrm{~h}$ resulted in 50\% vital teeth in Group 2, and 20\% in Group 1.

Despite obvious clinical differences in dental pulp colour and time of haemostasis of the amputated dental pulp between both groups, the final results did not differ so obviously with regard to the number of vital teeth at the end of the study. The total difference between both groups was relatively small and involved only three teeth.

Topically applied corticosteroids cause degenerative changes in the tissue and reduce the pulpal ability to form a hard tissue barrier in the presence of calcium hydroxide as mentioned 


\section{Uitto et al. (1975).}

In our experience flumetazone has a general excellent effect towards rapid elimination of trauma-induced oedema in animals. Its effect on traumatized dental pulp was seen after $48 \mathrm{~h}$. Though the effect of flumetazone on clinical appearance and bleeding time was seen especially after the fourth day, the final results showed only $30 \%$ difference in numbers of vital teeth between both groups of dogs. Despite the evident anti-inflammatory effect of flumetazone on dental pulp, its immunosuppressive effect influenced unfavourably the vitality of endodontically treated teeth with advancing time.

This study was performed on the teeth of dogs having the most of dentinal wall already developed. This means that the narrower the pulp chamber and root canal, the lower is the volume of pulp tissue and the intensity of defensive mechanisms.

This proves that the permanent teeth of one-year-old dogs, subjected to fracture while avoiding concussion, are able to remain vital for many months without any treatment and in unique cases the defect in pulp chamber closes as published by Capík et al. (2001).

The intramuscular use of corticosteroids (flumetazone) may increase non-significantly the success rate of vital pulpotomy, particularly in the teeth treated within $48 \mathrm{~h}$ after the trauma. The results should be examined roentgenologically and in the case of failure conventional endodontic therapy is recommended.

\section{Vplyv intramuskulárne podaného flumetazonu na odhalenú zubnú dreň u psov}

Metabolizmus zubnej drene je nepostrádatelný pre zachovanie plnohodnotného zdravotného stavu zuba. Úloha zubnej drene je obzvlášt nenahraditelná v prvých dvoch až troch rokoch života psov. Je to obdobie najintenzívnejšej produkcie sekundárneho dentínu zabezpečujúceho dostatočnú pevnosṫ zuba počas celého nasledujúceho života.

Táto práca porovnáva vplyv intramuskulárne podaného kortikosteroidu flumetazonu na vitalitu zubnej drene po parciálnej pulpectómii vykonanej v 24 hodinových intervaloch do štyroch dní po odhalení zubnej drene. U každého z desiatich pokusných psov, krížencov vo veku $20 \pm 2$ mesiace boli v koronálnej tretine zlomené korunky špičiakov, celkovo 40 zubov.

Piatim psom predstavujúcim prvú pokusnú skupinu bolo intramuskulárne aplikované antibiotikum amoxicilin v dávke $15 \mathrm{mg} / \mathrm{kg}^{-1} \mathrm{v} 48$ hodinových intervaloch do šiestich dní po endodontickom ošetrení zuba.

V druhej skupine bol okrem amoxicilinu ako v prvej skupine aplikovaný i.m. flumetazon $\mathrm{v}$ dávke $0.0125 \mathrm{mg} / \mathrm{kg}^{-1}$ prvé dva dni na dosiahnutie prolongovaného účinku.

Klinické vyšetrenia pred a röntgenologické vyšetrenia dva a tri mesiace po endodontickom ošetrení poukázali na určitý vplyv intramuskulárne podávaného flumetazonu avšak štatistická analýza pomocou $c^{2}$ testu nepotvrdila jeho signifikantnú významnost' $(p \leq 0,59)$.

Napriek nesignifikantnému vplyvu flumetazon môže zvýšit pravdepodobnosṫ zachovania vitality zubnej drene a tým dalšej produkcie dentínu zvlášt u vyvíjajúcich sa zubov.

\section{References}

CAPÍK, I, LEDECKY, V, ŠEVČÍK, A 2001: Dental Pulp and Dentin Deposition in Maturing Teeth of Dogs.

Proceedings 26th World Congress the World Small Animal Veterinary Association, 8.-11.VIII. 2001, Vancouver, p. 678

CVEK, M 1978: A Clinical Report on Partial Pulpotomy and Capping with Calcium Hydroxide in Permanent Incisors with Complicated Crown Fracture. J Endo 4: 232-237

CVEK, M, LUNDBERG, M 1983: Histological Appearance of Pulps after Exposure by a Crown Fracture, Partial 
418-434

EISNER, ER 1992: Three Endodontic Procedures: Pulp-Capping, Pulpotomy, and Apexification. Veterinary Medicine 5: 450-458

NYBORG, H 1958: Capping of a Pulp. The Processes Involved and Their Outcome, Odont. T 66: 296-364

PAVLICA, Z, JUNTES, P, POGAČNIK, M. 2000: Defence Reaction in Dental Pulp after Pulp capping and Partial Pulpectomy in Dogs. Acta Vet Hung 48: 23-34

THOLEN, MA: Endodontic Therapy. Concepts in Veterinary Dentistry. Veterinary Medicine Publishing, Lenexa, Kan., 1983, pp. 114-134

TRONSTAD, L, MJÖR, IA 1972: Capping of the Inflamed Pulp, Oral Surg 34: 477-485

UITTO, VJ, ANTILA, R, RANTA, R. 1975: Effects of Topical Glucocorticoid Medication on Collagen Biosynthesis in the Dental Pulp. Acta Odontol Scand 33: 287-298 


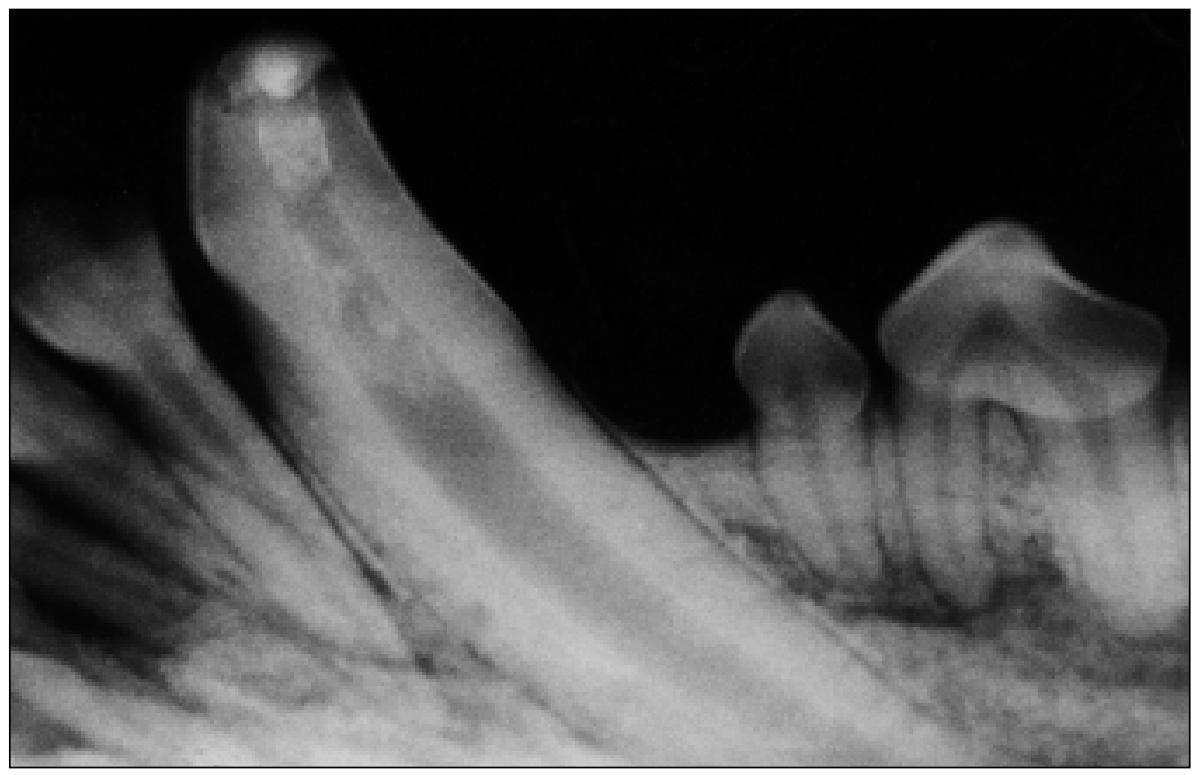

Fig.1. Roentgenological signs of dentinal bridging 2 months after endodontic therapy in the second group.

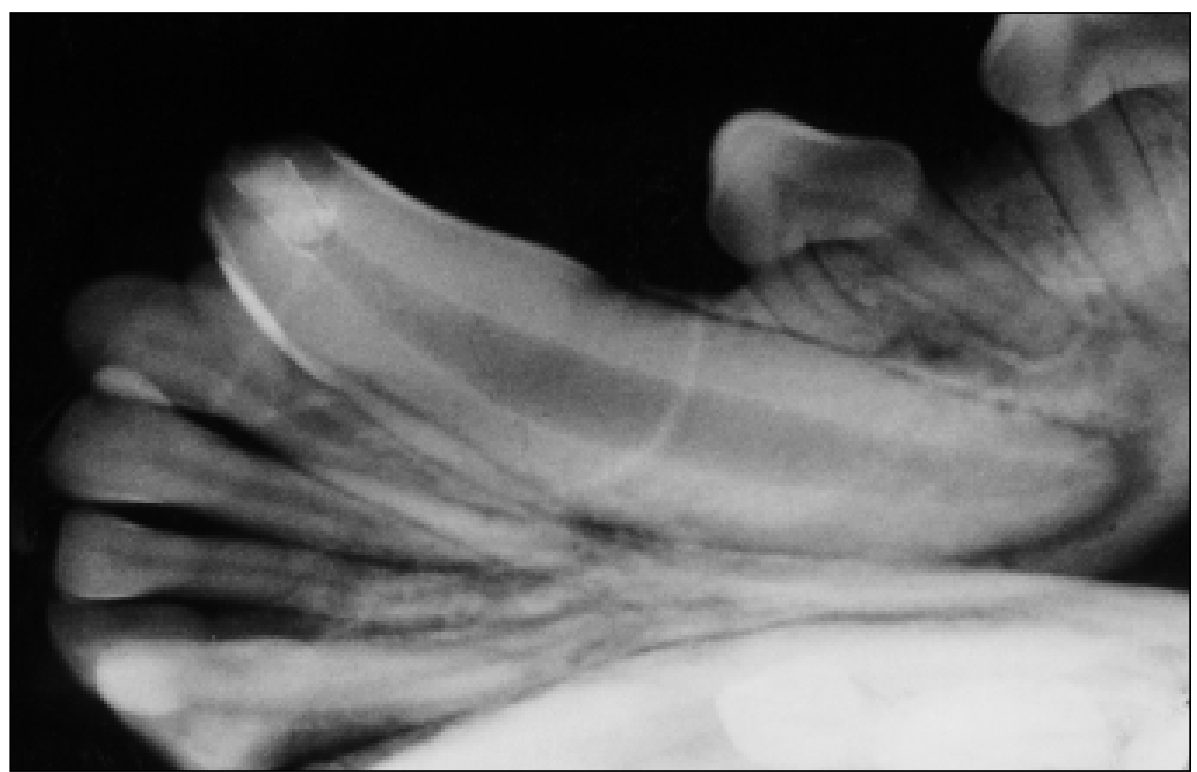

Fig. 2. Incomplete dentin production localized at the pulp chamber periphery. 


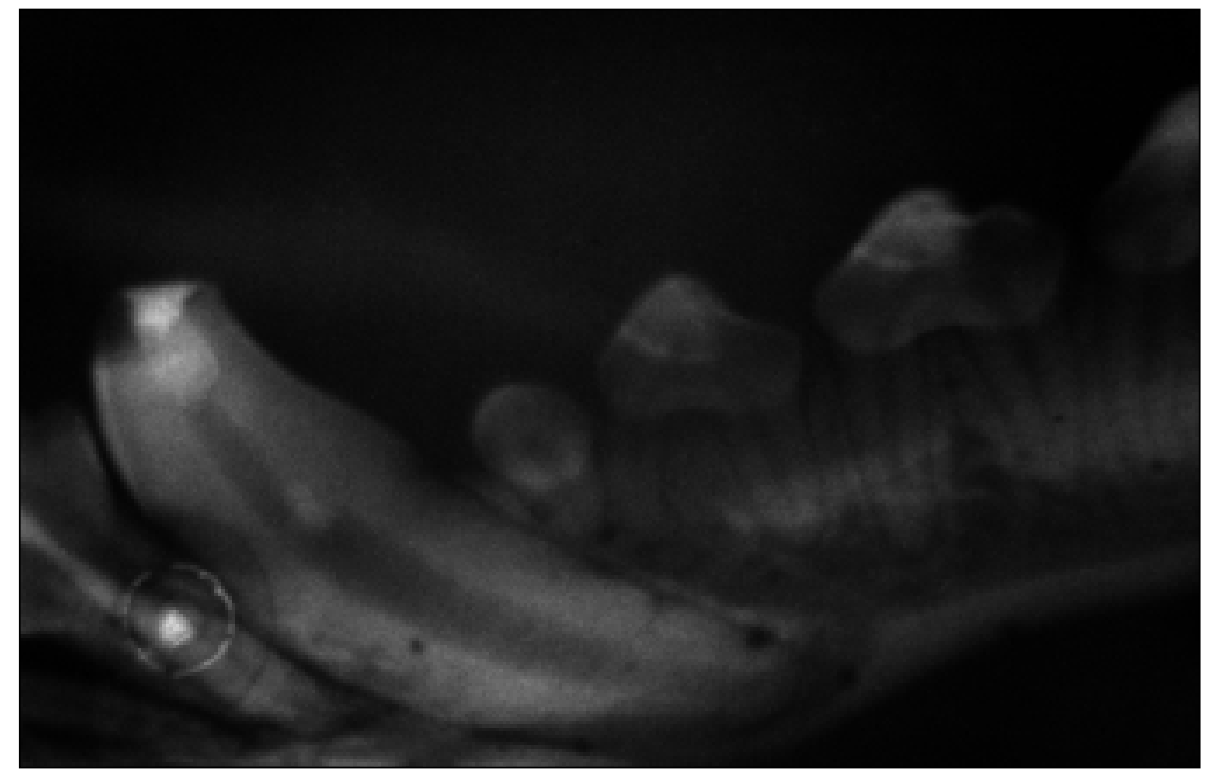

Fig. 3. Periapical inflamation (widened periodontal space, mainly periapical region) 
